\title{
Correlation of Knowledge and Attitude towards Exercise Habbit Action in FK USU Student
}

\author{
Muhammad Fadli' ${ }^{1, *}$, Muhammad Ikhsan Syafri Amir Nasution ${ }^{1}$, Dina Keumala Sari ${ }^{2}$, \\ Rina Amalia Carolina Saragih ${ }^{3}$, Dewi Masyithah Darlan ${ }^{4}$ \\ ${ }^{1}$ Faculty of Medicine, Universitas Sumatera Utara, Medan, Indonesia \\ ${ }^{2}$ Department of Nutrition Science, Universitas Sumatera Utara, Medan, Indonesia \\ ${ }^{3}$ Department of Pediatrics, Universitas Sumatera Utara, Medan, Indonesia \\ ${ }^{4}$ Department of Parasitology, Universitas Sumatera Utara, Medan, Indonesia
}

Received October 15, 2021; Revised December 3, 2021; Accepted December 13, 2021

\section{Cite This Paper in the following Citation Styles}

(a): [1] Muhammad Fadli, Muhammad Ikhsan Syafri Amir Nasution, Dina Keumala Sari, Rina Amalia Carolina Saragih, Dewi Masyithah Darlan, "Correlation of Knowledge and Attitude towards Exercise Habbit Action in FK USU Student," Universal Journal of Public Health, Vol. 9, No. 6, pp. 472 - 476, 2021. DOI: 10.13189/ujph.2021.090615.

(b): Muhammad Fadli, Muhammad Ikhsan Syafri Amir Nasution, Dina Keumala Sari, Rina Amalia Carolina Saragih, Dewi Masyithah Darlan (2021). Correlation of Knowledge and Attitude towards Exercise Habbit Action in FK USU Student. Universal Journal of Public Health, 9(6), 472 - 476. DOI: 10.13189/ujph.2021.090615.

Copyright $\odot 2021$ by authors, all rights reserved. Authors agree that this article remains permanently open access under the terms of the Creative Commons Attribution License 4.0 International License

\begin{abstract}
Background: Sport is a physically demanding activity that has a positive impact on the body. Exercise, in addition to maintaining physical fitness and being useful to one's health, it may protect a person from negative things such as stress and can be utilized as a kind of leisure. However, there are still many people who do not exercise properly. It is not necessarily excellent exercise for those who have good exercise knowledge, and it is not necessarily poor exercise for people who have less exercise knowledge. Exercising also disregards a person's age; people of all ages, young and old, are allowed to participate in sports they enjoy, such as aerobic and anaerobic activities. As previously said, in addition to maintaining physical fitness and being helpful to one's health, students should exercise to relieve tension induced by lectures. However, many students are overworked and do not consider exercise to be vital because they do not have spare time to participate in sports. Students will become unfit and unable to concentrate on the lecture subject as a result of this. Purpose: This study aims to determine whether there is a correlation between knowledge and attitudes towards the habit of exercising in students of the Faculty of Medicine, Universitas Sumatera Utara. Method: The research that will be conducted is an observational analytic study with a cross-sectional study approach. The sample to be studied in this study was 260 students of the Faculty of Medicine, Universitas Sumatera Utara who met the
\end{abstract}

inclusion criteria. The data used is primary data that will be obtained from questionnaires filled out online through the Line, WhatsApp, and Instagram applications. Results: Based on the data obtained using the chi-square method, then the results obtained were $p=0.202$ and $p=0.706$ ( $p$ $<0.05$ ). Conclusion: Based on these results, $\mathrm{H}_{\mathrm{o}}$ is accepted, so there is no correlation between knowledge and attitudes towards the habit of exercising in USU Medical Faculty students.

Keywords Sport, Type, Time, Benefits, Indicator

\section{Introduction}

Exercise is a requirement that cannot be overlooked. Exercise is a type of physical exercise that involves the movement of the body. It is intended that by exercising, a person will have a healthy and fit body that will help them be more productive in their daily lives. If a person isn't in good physical shape, it's safe to assume that his or her productivity will suffer. [3]

According to the national Basic Health Research (RISKESDAS) in 2018, the proportion of people aged 10 and above in North Sumatera who are less active in physical activity is $33,7 \%$. [7] Medan, with a rate of 
$46.95 \%$, is the district or city with the lowest level of physical activity. Dairi, with a proportion of $85.56 \%$, is the most active city or district in North Sumatera in terms of physical activity. [6]

Adults should exercise for 150 minutes each week, according to the Physical Activity Guidelines for Americans, and people who exercise consistently have a better quality of life. If someone wants to do high-intensity exercise, they should do it for at least 75 minutes every week. [8]

Students, as the driving force behind national transformation, play a critical role in nation-building. As a result, students must meet certain criteria in order to affect the destiny of their countries, one of which is that they must be healthy and fit. Physical activity or exercise will result in a fit and healthy body. According to Alfian research [1], students' busy schedules have a significant impact on physical activity, reducing their awareness of the need to exercise. The enormous study load each day, as well as the chores that must be accomplished, have an impact on this.

This is also corroborated by the findings of a study by Wahyudi [9], which found that out of 166 students at the University of Riau's Faculty of Medicine, just 30 (18,7\%) conduct exercise regimens. This is due to the fact that medical students have hectic schedules and little leisure time.

\section{Methods}

This study took a cross-sectional approach and used an analytical study design. The goal is to determine the relationship between exercise habits and knowledge, attitudes, and actions among FK USU students.

This research will be carried out for 3 months which will start from July until September 2021. The research location will held in Faculty Of Medicine Universitas Sumatera Utara, Medan

The number of samples in this study was determined based on the sample size formula with the Slovin formula:

$$
\mathrm{n}=\frac{N}{1+N e^{2}}
$$

The number of samples acquired using these procedures were 260 people out of a total population of 753 people. The population was divided into sub-populations/strata using the sampling technique. This technique is carried out by gathering data on the entire student batch of 2018, 2019, and 2020, and then using the formula No of Samples $=$ No of Subpopulations/No of Populations x No of Samples required to find the number of samples required for each class.

$$
\begin{gathered}
2018=252 / 753(260)=87,01 \approx 87 \\
2019=243 / 753(260)=83,90 \approx 84 \\
2020=258 / 753(260)=89,08 \approx 89 \\
\text { Total }=260
\end{gathered}
$$

\section{Results}

The collection of the data was conducted from July to August 2021 by giving questionnaires to the Faculty of Medicine, Universitas Sumatera Utara students.

The following are data on results collected from respondents:

Table 1. Frequency distribution of respondent characteristics

\begin{tabular}{ccc}
\hline Gender & Frequency & \%age \\
\hline Man & 93 & $35,8 \%$ \\
Women & 167 & $64,2 \%$ \\
Age & & \\
17 & 3 & $1,2 \%$ \\
18 & 44 & $16,9 \%$ \\
19 & 80 & $30,8 \%$ \\
20 & 78 & $30 \%$ \\
21 & 46 & $17,7 \%$ \\
22 & 7 & $2,7 \%$ \\
23 & 1 & $0,4 \%$ \\
24 & 1 & $0,4 \%$ \\
Batch & & \\
2018 & 87 & $33,5 \%$ \\
2019 & 84 & $32,3 \%$ \\
2020 & 89 &
\end{tabular}

Women made up the majority of the participants in this study, with 167 women (64.2\%) and 93 men $(35.8 \%)$. Students aged 19 years $(30.8 \%)$ participated the most in this survey, while those aged 23 and 24 years participated the least $(0.4 \%)$. The frequency distribution based on generation, namely the 2018 batch of 87 individuals $(33.5 \%)$, the 2019 batch of 84 people $(32.3 \%)$, and the 2020 batch of 89 people, has been determined from the beginning using the formula $(34.2 \%)$.

Table 2. Sample Knowledge Level Distribution

\begin{tabular}{ccc}
\hline Knowledge & Frequency & \%age \\
\hline Good & 64 & $24,6 \%$ \\
Sufficient & 139 & $53,5 \%$ \\
Poor & 57 & $21,9 \%$ \\
Total & 260 & $100 \%$ \\
\hline
\end{tabular}

It is well known that students' understanding of sports is sufficient, with as many as 139 people agreeing (53.5\%).

Table 3. Sample Attitude Level Distribution

\begin{tabular}{ccc}
\hline Knowledge & Frequency & \%age \\
\hline Good & 169 & $65.0 \%$ \\
Sufficient & 85 & $32,70 \%$ \\
Poor & 6 & $2,30 \%$ \\
Total & 260 & $100 \%$ \\
\hline
\end{tabular}

It is well known that students' attitude regarding sports is in good level, with as many as 169 people agreeing (65\%). 
Table 4. Sample Action Level Distribution

\begin{tabular}{ccc}
\hline Knowledge & Frequency & \%age \\
\hline Good & 76 & $29,2 \%$ \\
Sufficient & 130 & $50,0 \%$ \\
Poor & 54 & $20,8 \%$ \\
Total & 260 & $100 \%$ \\
\hline
\end{tabular}

It is well known that the action level is sufficient, with up to 130 persons participating $(50 \%)$.

The table below shows the level of knowledge, attitudes, and exercise habits of students at Faculty of Medicine Universitas Sumatera Utara by age.

Table 5. Distribution Based Sample Age

\begin{tabular}{cccccccccc}
\hline & \multicolumn{3}{c}{ Knowledge } & \multicolumn{3}{c}{ Attitude } & \multicolumn{3}{c}{ Behavior } \\
\cline { 2 - 9 } & Good & Suff & Poor & Good & Suff & Poor & Good & Suff & Poor \\
\hline 17 & 1 & 1 & 1 & 2 & 1 & 0 & 0 & 3 & 0 \\
18 & 9 & 20 & 15 & 24 & 18 & 2 & 11 & 25 & 8 \\
19 & 21 & 43 & 16 & 61 & 17 & 2 & 27 & 38 & 15 \\
20 & 24 & 41 & 13 & 47 & 31 & 0 & 24 & 37 & 17 \\
21 & 7 & 29 & 10 & 29 & 15 & 2 & 12 & 21 & 13 \\
22 & 2 & 3 & 2 & 6 & 1 & 0 & 2 & 5 & 0 \\
23 & 0 & 1 & 0 & 0 & 1 & 0 & 0 & 0 & 1 \\
24 & 0 & 1 & 0 & 0 & 1 & 0 & 0 & 1 & 0 \\
Total & 64 & 139 & 57 & 169 & 85 & 6 & 76 & 130 & 54 \\
\hline
\end{tabular}

The sample aged 18-24 years was found to have sufficient knowledge, with the distribution of the sample aged 18 years totaling 20 people $(7.7 \%), 19$ years old totaling 43 people $(16.5 \%)$, 20 years old totaling 41 people (15.8\%), and 29 individuals aged 21 years totaling 29 people $(11.2 \%), 3$ people aged 22 years $(1.2 \%)$, and 1 person each aged 23 and 24 years $(0.4 \%)$. The sample aged 17-22 years had a decent attitude level, while the sample aged 23 and 24 years had an adequate attitude level, with the distribution of the sample aged 17 years comprising 2 persons $(0.8 \%)$, and the sample aged 18 years totaling 24 people. $(9.2 \%), 61$ people aged $19(23.5 \%), 47$ people aged $20(18.1 \%), 29$ people aged $21(11.2 \%), 6$ people aged 22 (2.3\%), and 1 person each aged 23 and 24 (2.3\%). (0.4\%). The sample aged 17-22 and 24 years had sufficient action, while the sample aged 23 years had good action, with the distribution of the sample aged 17 years being 3 people (1.2\%), aged 18 years 25 people $(9.6 \%), 19$ years 38 people $(14.6 \%), 20$ years 37 people $(14.2 \%), 21$ years old 21 $(8.1 \%), 22$ years old 5 people $(1.9 \%)$, and one person aged 24 years $(0.4 \%)$.

Table 6. Distribution by Gender of Sample

\begin{tabular}{cccccccccc}
\hline Gend & \multicolumn{3}{c}{ Knowledge } & \multicolumn{3}{c}{ Attitude } & \multicolumn{3}{c}{ Action } \\
\hline & G & S & P & G & S & P & G & S & P \\
\hline M & 26 & 48 & 19 & 64 & 27 & 2 & 24 & 51 & 18 \\
W & 38 & 91 & 38 & 105 & 58 & 4 & 52 & 79 & 36 \\
Total & 64 & 139 & 57 & 169 & 85 & 6 & 76 & 130 & 54 \\
\hline
\end{tabular}

The sample with man gender had a sufficient degree of knowledge (48 individuals, or $18.5 \%$ ), a good attitude (64 people, or $24.6 \%$ ), and a sufficient level of action (51 people, or $51 \%)(19,6 \%)$. Meanwhile, 91 people $(35 \%)$ in the female gender sample have a sufficient level of knowledge, 105 people $(40.4 \%)$ have a good attitude, and 79 people have a sufficient degree of action $(30.4 \%)$.

The batch of 2018 sample was found to have a sufficient level of knowledge, a positive attitude, and sufficient action, with 51 individuals (19.6\%) for level of knowledge, 56 people $(21.5 \%)$ for attitude, and 40 people for activity (15.4\%). With 47 people (18.1\%) for level of knowledge, 58 people $(22.3 \%)$ for attitudes, and 44 people $(16.1 \%)$ for actions, the sample with the batch of 2019 has a sufficient level of knowledge, good attitudes, and sufficient actions. With a division of 41 individuals $(15.8 \%)$ for level of knowledge, 55 people (21.2\%) for attitude, and 46 people $(17.8 \%)$ for action, the sample with the batch of 2020 has a sufficient level of knowledge, good attitude, and sufficient action.

Table 7. Distribution by Batch of Sample

\begin{tabular}{cccccccccc}
\hline \multirow{2}{*}{ Batch } & \multicolumn{3}{c}{ Knowledge } & \multicolumn{3}{c}{ Attitude } & \multicolumn{3}{c}{ Action } \\
\cline { 2 - 10 } & G & S & P & G & S & P & G & S & P \\
\hline 2018 & 18 & 51 & 18 & 56 & 30 & 1 & 28 & 40 & 19 \\
2019 & 25 & 47 & 12 & 58 & 24 & 2 & 21 & 44 & 19 \\
2020 & 21 & 41 & 27 & 55 & 31 & 3 & 27 & 46 & 16 \\
Total & 64 & 139 & 57 & 169 & 85 & 6 & 76 & 130 & 54 \\
\hline
\end{tabular}


Table 8. Distribution of the Correlation of Knowledge with Action

\begin{tabular}{cccccccccc}
\hline & \multicolumn{1}{c}{ Action } \\
\cline { 2 - 10 } Kno & \multicolumn{2}{c}{ Poor } & \multicolumn{2}{c}{ Sufficient } & & Good & & Total \\
\cline { 2 - 10 } & F & \% & F & \% & F & \% & F & \% \\
\hline Poor & 15 & 5,8 & 31 & 11,9 & 11 & 4,2 & 57 & 21,9 \\
Suff & 30 & 11,5 & 68 & 26,2 & 41 & 15,8 & 139 & 53,5 \\
Good & 9 & 3,5 & 31 & 11,9 & 24 & 9,2 & 64 & 24,6 \\
Total & 54 & 20,8 & 130 & 50 & 76 & 29,2 & 260 & 100 \\
\hline
\end{tabular}

Table 9. Distribution of the Relationship between Attitudes and Actions

\begin{tabular}{ccccccccc}
\hline & \multicolumn{1}{c}{ Action } \\
\cline { 2 - 9 } Att & \multicolumn{2}{c}{ Poor } & \multicolumn{2}{c}{ Sufficient } & \multicolumn{2}{c}{ Good } & \multicolumn{2}{c}{ Total } \\
\cline { 2 - 9 } & F & \% & F & \% & F & \% & F & \% \\
\hline Poor & 2 & 0,8 & 3 & 1,2 & 1 & 0,4 & 6 & 2,3 \\
Suff & 16 & 6,2 & 47 & 18,1 & 22 & 8,5 & 85 & 32,7 \\
Good & 36 & 13,8 & 80 & 30,8 & 53 & 20,4 & 169 & 65 \\
Total & 54 & 20,8 & 130 & 50 & 76 & 29,2 & 260 & 100 \\
\hline
\end{tabular}

It reveals that out of 260 responders, 54 have taken poor action (20.8\%), 130 have taken sufficient action (50\%), and 76 have taken good action (29.2\%). Then, out of 260 respondents, it was discovered that 57 had poor knowledge (21.9\%), 139 had sufficient knowledge (53.5\%), and 64 had good knowledge (24,6\%). Table 4.8 also shows that among the 54 respondents who took insufficient action, 15 had insufficient knowledge (5.8\%), 30 had sufficient knowledge (11.5\%), and 9 had good knowledge. 3.5\%. There are 130 people who have taken adequate action. There are 31 people who have a poor degree of knowledge (11.9\%), 68 people who have a sufficient level of knowledge (26.2\%), and 31 people who have a good level of knowledge (11.9\%). 76 people responded with positive behaviors. There are 11 people with a poor level of knowledge (4.2\%), 41 people with a sufficient level of knowledge (15.8\%), and 24 people with a good level of knowledge (2.4\%). (9.2\%).

It reveals that out of 260 responders, 54 have taken poor action (20.8\%), 130 have taken sufficient action (50\%), and 76 have taken good action (29.2\%). Then, out of 260 respondents, it was discovered that 6 had a poor attitude $(2.3 \%), 85$ had a sufficient attitude (32.7\%), and 169 had a good attitude $(65 \%)$. According to table 4.9 , there are 2 respondents with poor attitudes $(0.8 \%), 16$ respondents with sufficient attitudes (6.2\%), and 36 persons with good attitudes among the 54 respondents with poor action. $(13.8 \%)$. There are 130 people who have taken adequate action. There are 3 responders with a negative attitude $(1.2 \%), 47$ with a sufficient attitude (18.1\%), and 80 with a positive attitude (80). (30.8\%). There are 76 responses with a positive attitude, 1 respondent with a poor attitude $(0.4 \%)$, 22 respondents with a sufficient attitude (8.5\%), and 53 respondents with a positive attitude (20.4\%). Using the chi-square approach, researchers discovered that there was a difference in the association between knowledge and attitudes toward the practice of exercising habits in Faculty Of Medicine Universitas Sumatera Utara, with knowledge having a $p$ value of 0.202 and attitude having a $p$ value of 0.706 ( $p$ 0.05). According to these findings, there is no correlation between knowledge and attitudes about the exercise habit.

\section{Discussion}

In the preceding discussion, it was discovered that there was no correlation between knowledge and action, with a $p$ value of 0.202 , and that there was a $p$ value of 0.706 for the correlation between attitudes and actions. Because $\mathrm{H}_{\mathrm{o}}$ is accepted because the $\mathrm{p}$ value is less than 0.05 , it may be assumed that there is no correlation between knowledge and attitudes about exercising in FK USU students. This is similar to previous studies, such as Febrianto [2] The Relationship Between Knowledge and Attitude with Exercise Habits at Al-Quran Al-Amin Islamic Boarding School Santri Purwokerto, which found no relationship between knowledge and habits $(p=0.124)$ and a correlation between attitude and exercise habits $(\mathrm{p}=0.756)$. Hidayati [5] discovered that her results are similar with this study. In her study, she discovered that out of 95 respondents with good knowledge, 75 (78.9\%) had sufficient attitudes and physical activity practices, while 52 $(54.7 \%)$ did not. There was no correlation between knowledge $(\mathrm{p}=0.282)$ and attitudes $(\mathrm{p}=0.444)$ regarding physical activity behavior, according to $44.2 \%$ of 
respondents. In their study entitled The Relationship of Knowledge and Attitudes of Pregnant Women about Exercise, Hapsari et al [4] also mentioned that there is no correlation between knowledge and attitudes toward exercise during pregnancy. In his research, he discovered that out of 50 persons, $29(58 \%)$ had strong knowledge and $32(64 \%)$ had a positive attitude, with a $\mathrm{p}$ value of 0.267 . The benefit of this research is

(1) For researchers, it can be seen that there is no correlation between knowledge, attitude, and habitual exercise in Faculty of Medicine Universitas Sumatera Utara so that it can be used as a basis for providing education in the future.

(2) The Students of Faculty of Medicine Universitas Sumatera Utara and the general public can increase their knowledge about exercise habits and can be a source of reading so they can have a better understanding of it.

(3) For further research, it is hoped that the results of this study can be used as a basis, thereby increasing knowledge, attitudes, and actions about exercise habits and as a literature review for other researchers. It is hoped that future researchers will research this because there is still a lack of research available on this study.

\section{Conclusion}

The results were found to be $p=0.000(p<0.05)$. Based on the results, the $\mathrm{H}_{0}$ was agreed, so there was not a correlation between knowledge and attitude towards exercise habit action in FK USU students.

\section{REFERENCES}

[1] Alfian, M.R. 2018, 'Hubungan Kebiasaan Berolahraga dengan Tingkat Stres Mahasiswa Program Studi Ilmu Keperawatan Stikes Sari Mulia Banjarmasin', p.53. http://repository.unism.ac.id/id/eprint/168

[2] Febrianto, A., 2019, 'Hubungan Antara Pengetahuan dan Sikap dengan kebiasaan Berolahraga pada Santri Pondok Pesantren Al-Quran Al-Amin Purwokerto http://repository.unsoed.ac.id/id/eprint2096 p.1

[3] Firdaus, K. 2012, Psikologi Olahraga: Teori dan Aplikasi, Fakultas Keolahragaan Universitas Negeri Padang Press, Padang. p.v

[4] Hapsari A., Wardani H.E., Kartikasari, D., 2019, 'Hubungan Pengetahuan dan Sikap Ibu Hamil Tentang Olahraga Selama Masa Kehamilan' Vol.2 No.2 (2019): Journal for Quality in Womens's Health https;//doi.org/10.30994/jgwh.v2i2.31

[5] Hidayati, N., 2010, 'Hubungan Pengetahuan dan Sikap Terhadap Perilaku Aktivitas Fisik pada Masyarakat Kota Banda Aceh. p.1

[6] Lembaga Penerbit Badan Penelitian dan Pengembangan Kesehatan (LPB). 2019. 'Laporan Provinsi Sumatera Utara, RISKESDAS 2018', Kementrian Kesehatan RI, Jakarta. p. 300

[7] Lembaga Penerbit Badan Penelitian dan Pengembangan Kesehatan (LPB). 2019. 'Laporan Nasional, RISKESDAS 2018', Kementrian Kesehatan RI, Jakarta.p.340

[8] Rodgers, A.B. 2018, Physicall Activity Guidelines for American $2^{\text {nd }}$ Edition, Central Disease Control (CDC), Washington DC. p. 8

[9] Wahyudi, R., Bebasari, E., Nazriati, E. 2015, 'Hubungan Kebiasaan Berolahraga dengan Tingkat Stres pada Mahasiswa Kedokteran Universitas Riau Tahun Pertama', Jurnal Online Mahasiswa Fakultas Kedokteran, Vol 2, No.2. p.6 